\title{
Ultrastructural Changes in the Liliequist Membrane in the Hydrocephalic Process and Its Implications for the Endoscopic Third Ventriculostomy Procedure
}

\author{
Hidrosefalik Süreçte Liliequist Membranı Yapısının Ultrastrüktürel \\ Değişiklikleri ve Endoskopik Üçüncü Ventrikülostomi Prosedürü \\ Açssından Önemi
}

\author{
Volkan ETUS ${ }^{1}$, Seyhun SOLAKOGLU², Savas CEYLAN ${ }^{1}$ \\ ${ }^{1}$ Kocaeli University, Faculty of Medicine, Department of Neurosurgery, Kocaeli, Turkey \\ ${ }^{2}$ Istanbul University, Faculty of Medicine, Department of Histology and Embriology, Istanbul, Turkey
}

Correspondence address: Volkan ETUS / E-mail: drvolkanetus@yahoo.com

\begin{abstract}
AIM: Fenestration of Liliequist membrane (LM) during endoscopic third ventriculostomy (ETV) is extremely important for the success of the procedure. It is noteworthy that LM usually shows a tough and dense stucture in long-standing hydrocephalus cases different from its usual arachnoidal membrane-like structure observed in new-onset hydrocephalus cases. The structural variation of LM in different hydrocephalic states was investigated histologically in this study.

MATERIAL and METHODS: Specimens of LM obtained during endoscopic fenestration in 11 cases were examined under transmissionelectron-microscopy. Six cases had long-standing hydrocephalus and five had new-onset triventricular hydrocephalus. None of the cases had a history of infection or hemorrhage.

RESULTS: In cases with long-standing hydrocephalus, ultrastructural examinations revealed the existence of regular and dense bundles of type-I collagen among the fibroblast-like cells, which were closely connected by dense desmosomes and gap-junctions. In cases with newonset hydrocephalus, it was observed that the cells usually had long cytoplasmic extentions and were connected with loose desmosomes. Sparse type-I collagen bundles were observed rarely among the cells.

CONCLUSION: These results suggest that the structure of LM may change with the duration of the hydrocephalic process. This may help explain the tough and dense LM stucture observed during the ETV procedure in cases with long-standing-hydrocephalus.

KEYWORDS: Endoscopic third ventriculostomy, Hydrocephalus, Liliequist membrane, Transmission electron microscopy

öz

AMAÇ: Endoskopik üçüncü ventrikülostomi (ETV) işleminde Liliequist membranının (LM) açılması, ETV başarısı açısından kritik öneme sahiptir. LM'nın özellikle uzun süreli hidrosefali olgularında, yeni gelişen hidrosefali olgularına kıyasla daha dirençli ve kalın yapıda oluşu dikkat çekicidir. Yazıda farklı hidrosefali süreçlerinde gözlenen bu yapısal farklılığın histolojik düzeyde incelenmesi amaçlanmıştır.

YÖNTEM ve GEREÇ: ETV uygulanan 11 olguda LM açılması sırasında elde edilmiş olan membran parçaları transmisyon elektron mikroskopisinde incelenmiştir. Olguların altı tanesinde "uzun süreli hidrosefali", beşinde ise "yeni başlangıçlı hidrosefali" sözkonusu olup, hiçbirinde geçirilmiş enfeksiyon veya kanama öyküsü yoktu.

BULGULAR: Uzun süreçli hidrosefalinin sözkonusu olduğu olgulardan alınan dokularda fibroblast morfolojisi sergileyen hücrelerin arasında düzenli ve yoğun demetler halinde tip I kollajenin varlığı dikkat çekti. Kollajen demetleri arasındaki hücrelerin sık desmozomlarve gap junctionlar aracılığıyla bağlantılı oldukları görüldü. Yeni başlangıçlı hidrosefali olgularına ait örneklerde ise hücrelerin uzun sitoplazmik uzantılara sahip oldukları ve seyrek desmozomlar aracılığıyla bağlantılı olmalarının yanısıra aralarında nadiren seyrek tip I kollajen lifleri bulunduğu dikkat çekti. SONUÇ: Bu bulgular, LM'nın hidrosefalinin süresine bağlı olarak fibrozitesinin artması yönünde bir yapısal değişiklik içerisine girdiğini düşündürmektedir. Mevcut veriler, uzun süreçli hidrosefalisi olan olgularda ETV işlemi sırasında karşılaşılan dirençli ve kalın LM natürünü açıklamada yardımcı olabilir.
\end{abstract}

ANAHTAR SÖZCÜKLER: Endoskopik üçüncü ventrikülostomi, Hidrosefali, Liliequist membranı, Transmisyon elektron mikroskopi 


\section{INTRODUCTION}

Endoscopic third ventriculostomy (ETV) combines a minimally invasive approach with visual control of manipulations, and is currently considered the best alternative to shunt systems in the treatment of hydrocephalus. With ETV, the floor of the third ventricle is fenestrated; then, the flow of cerebrospinal fluid (CSF) is diverted from the third ventricle to the interpeduncular cistern in which the arachnoid membranes and trabeculae are extremely luxuriant and complicated.

Among the arachnoid membranes residing in the interpeduncular cistern, the Liliequist membrane, which extends from the upper border of the dorsum sellae to the anterior edge of the mamillary bodies, has been found to be extremely important in the neuroendoscopic management of hydrocephalus. Failure to open this membrane can lead to the failure of the ETV procedure $(1,3,15)$.

In our experience with the ETV technique in over 250 cases, we have observed that the Liliequist membrane was usually thick and tough, especially in long-standing hydrocephalus cases, as compared to its usual arachnoidal membrane-like structure observed in newly onset hydrocephalus cases (Figures 1A, B). Such thickened nature of the Liliequist membrane has frequently led the ETV procedure to become technically much more demanding during its fenestration. We suggest that the duration of hydrocephalus might contribute to changes in the structure of the Liliequist membrane. No mention has been made of the structural variations of the Liliequist membrane in hydrocephalus process in the literature. The present study intended to confirm and demonstrate the possible differences in Liliequist membrane structure between long-standing cases and new-onset hydrocephalus cases. The tissue specimens that have been obtained during the fenestration of Liliequist membrane in ETV procedures of both long-standing and new-onset hydrocephalus cases were examined under transmission electron microscope. To our knowledge, this is the first study to evaluate the structure of the Liliequist membrane in the hydrocephalic process.

\section{MATERIAL and METHODS}

\section{Patients and endoscopic third ventriculostomy procedure}

Specimens of Liliequist membrane were analyzed in 11 patients who underwent the ETV procedure between July 2007 and July 2010. The data was collected prospectively. In the study plan, the selection criteria for the patients were the cause and the history of the hydrocephalus. Only the hydrocephalus cases due to primary aqueductal stenosis, idiopathic chronic hydrocephalus or LOVA (longstanding overt ventriculomegaly of adulthood) were included in the study. Patients with a history of previous operations (including previous ETV, external ventricular drainage or ventriculoperitoneal shunt insertion), previous CSF infection or intracranial hemorrhage were not included. According to these criteria, the study included 11 patients. Their ages ranged between 5 and 58 years. Regarding the duration and the pathophysiology of hydrocephalus, 6 patients had longstanding hydrocephalus and five had new-onset triventricular hydrocephalus. All surgical and histopathological procedures were performed with the informed consent of the patients.

All ETVs have been performed with a similar technique using the freehand method by the same neurosurgeon (VE) employing 0 degree rigid rod lens neuroendoscopes (outer diameter of $4.0 \mathrm{~mm}$ or $3.5 \times 2.5 \mathrm{~mm}$ by Karl Storz GmbH \& Co., Tuttlingen, Germany). In our experience on ETV procedures in the last 10 years, we usually prefer to cut out or tear off a small piece of membrane gently by using endoscissors or grasping forceps in order to maintain an adequate opening in the Liliequist membrane, especially in cases of dense or thick membranes or in cases where the interpedincular cistern is narrow (Figures 2A-D). In the present study, the Liliequist membrane specimens examined were all obtained to widen the basal arachnoidal opening in ETV procedures as mentioned above.
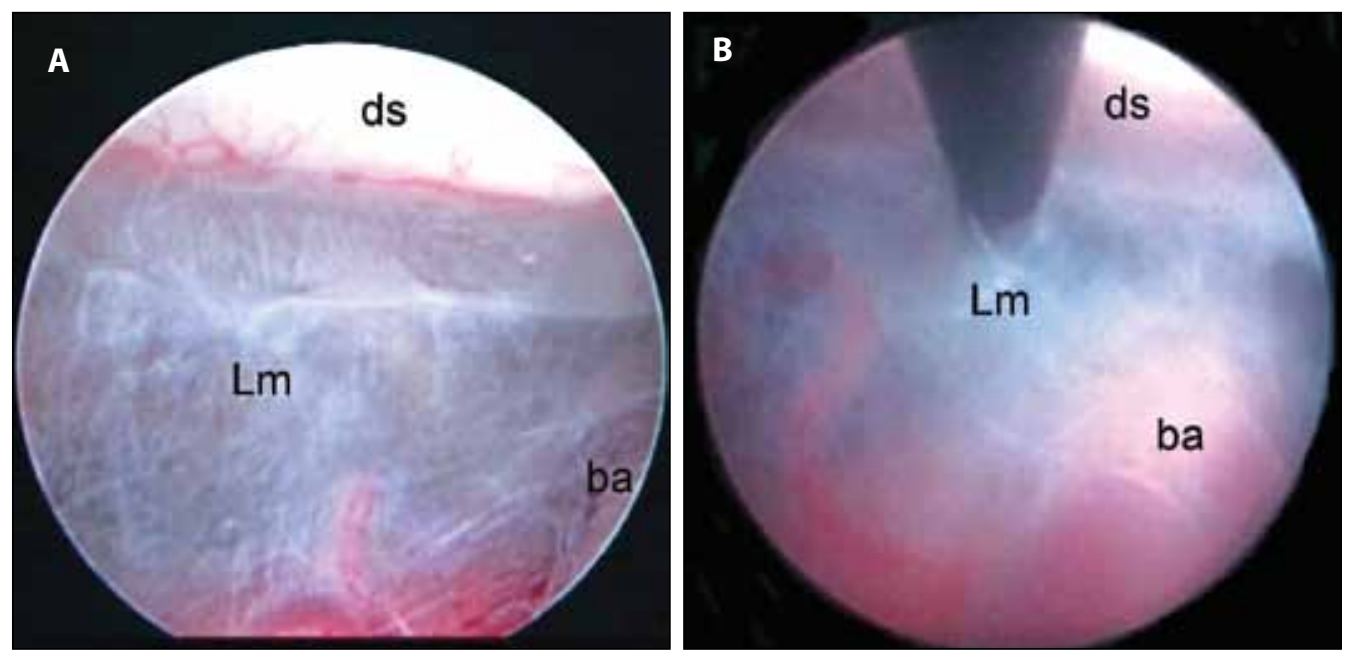

Figure 1: Neuroendoscopic views of the the Liliequist membrane.

A) The usual arachnoidal membrane-like appearance of the Liliequist membrane in a newly onset hydrocephalus case. B) Dense and opaque appearance of the Liliequist membrane in a longstanding hydrocephalus case.

ba: Basilar artery,

ds: Dorsum sellae,

Lm: Liliequist membrane. 


\section{Electron Microscopic Examination and Ultrastructural Evaluation}

Specimens of Liliequist membrane were fixed in $2.5 \%$ gluteraldehyde for one hour at $+4{ }^{\circ} \mathrm{C}$ and were then washed in cold cocodylate buffer ( $0.05 \mathrm{M}$; pH 7.4) two times for 10 minutes each. Samples were then postfixed in $1 \%$ osmium tetroxide for one hour and were dehydrated in a series of graded alcohols (50\%, 70\%, 90\%, $96 \%$ and $100 \%$ respectively). Propylene oxide-Epon 812 treated specimens were embedded in Epon-812 embedding media. Semithin sections (1 $\mu \mathrm{m})$ were obtained via Reichert microtome and were stained with toluidine blue. Ultrathin sections were prepared via using LKB ultramicrotome and were stained with uranyl acetatelead citrate. Transmission electron microscopic examination was performed using a Jeol-1011B electron microscope (Leo Company, Germany) with Megaview digital imaging system.

\section{RESULTS}

No complications were encountered in the ETV procedures of the cases. Follow-up was for a mean of 2 years (mean 24.72 months, range 5-41 months).
In cases with new-onset hydrocephalus, ultrastructural evaluation of the Liliequist membrane specimens showed that the cells usually resembled flat fibroblasts with long cytoplasmic extentions (Figure 3) and were connected by loose desmosomes (Figure 4). The cells were usually observed to gather around heaps of amorphic flocculant material and we rarely noticed sparse bundles of type-I collagen among the cells (Figure 5).

In cases with long-standing hydrocephalus, ultrastructural examinations revealed that the cells usually showed an active fibroblast morphology (Figure 6) and were closely connected by dense desmosomes and gap-junctions (Figure 7). The fibroblast-like cells were observed to have ovoid shaped nuclei and dark cytoplasms which included actin filaments inside (Figure 8). Among the cells, we frequently observed regular and dense bundles of type-I collagen (Figure 9), which suggested that the fibrous construction of Liliequist membrane might have increased in cases with long-standing hydrocephalus.
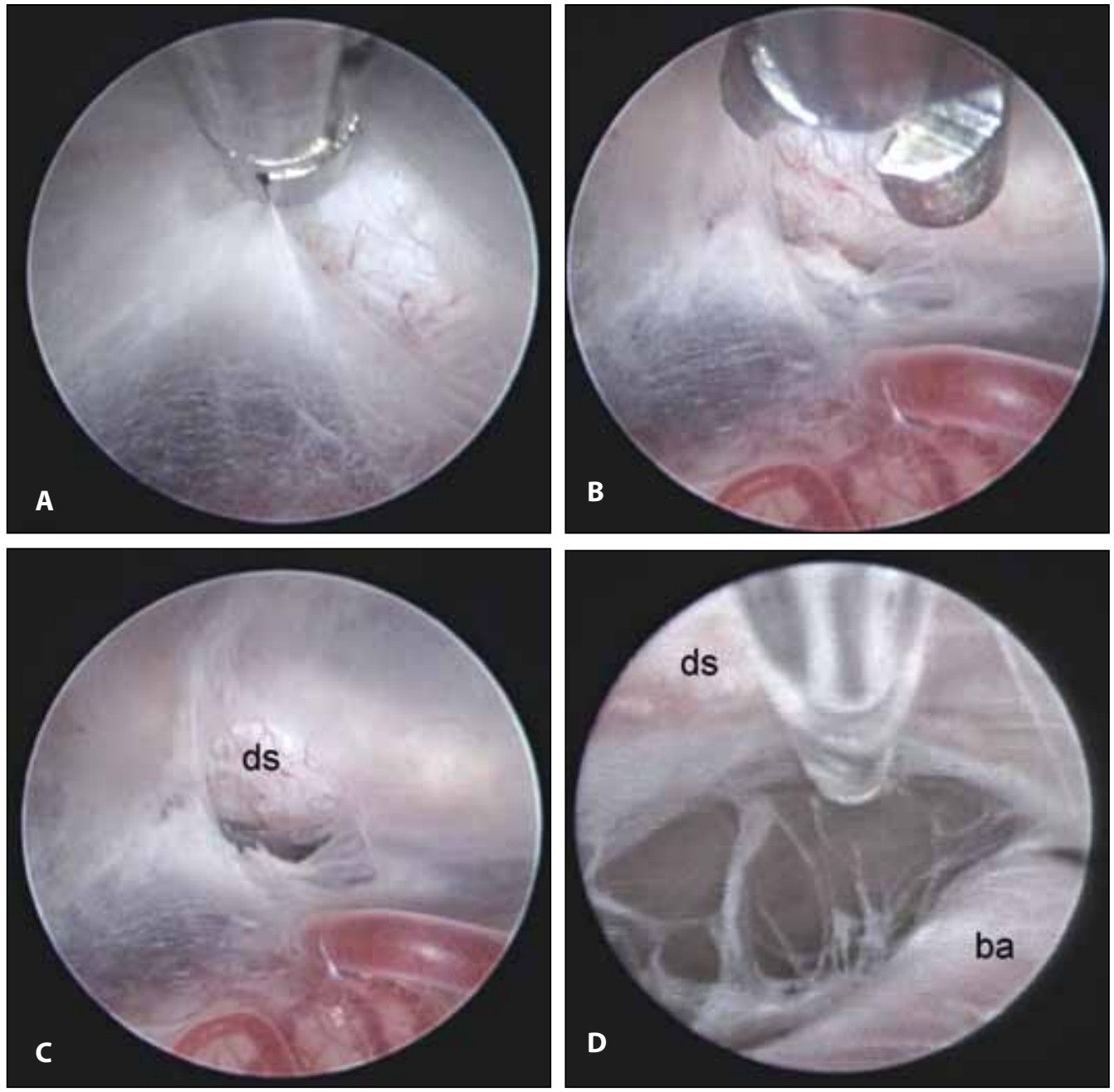

Figure 2: Neuroendoscopic views showing the surgical steps in the fenestration of Liliequist membrane during endoscopic third ventriculostomy procedure. A-B) Dense and thick Liliequist membrane is being gently perforated near to its attachment site to the dorsum sella by using grasping forceps. C) Neuroendoscopic view showing the Liliequist membrane after being perforated. A small piece of membrane has been removed. Note that dorsum sellae is visible from that aperture.

D) Neuroendoscopic view showing that the fenestration site on the Liliequist membrane has been greatly widened by balloon dilatation inorder to maintain an adequate opening for cerebrospinal fluid flow.

ba: Basilar artery ds: Dorsum sellae. 

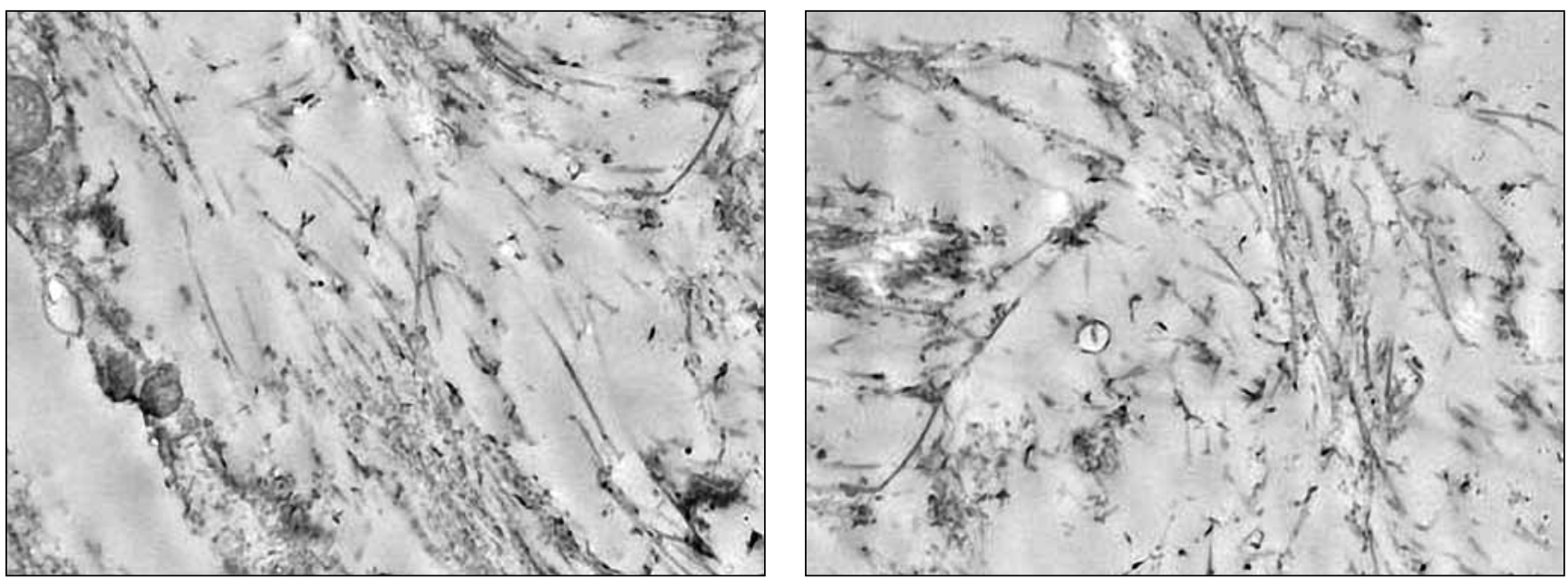

Figure 3: Examples for new onset hydrocephalus cases are viewed under X5000 magnification. Uniformly, cells have long cytoplasmic extentions resemblig flat fibroblasts.
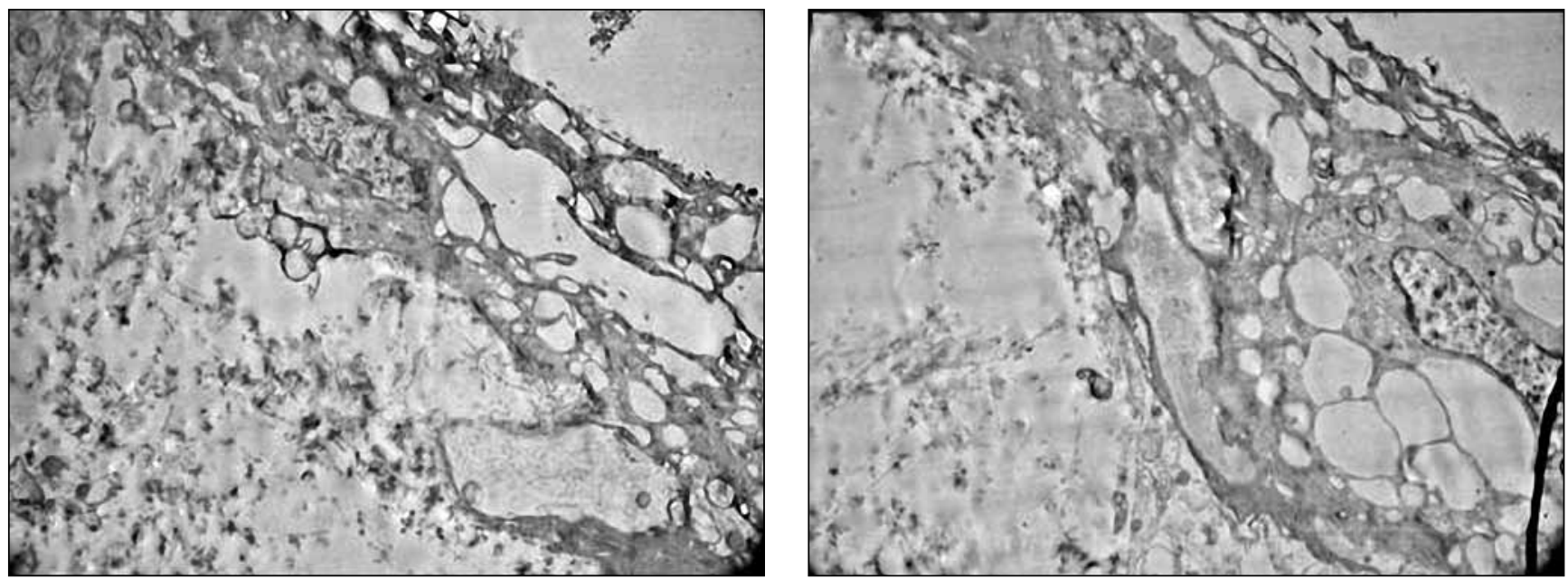

Figure 4: Examples for new onset hydrocephalus cases are viewed under X5000 magnification. Cells in appearance of flat fibroblasts are connected with loose desmosomes.
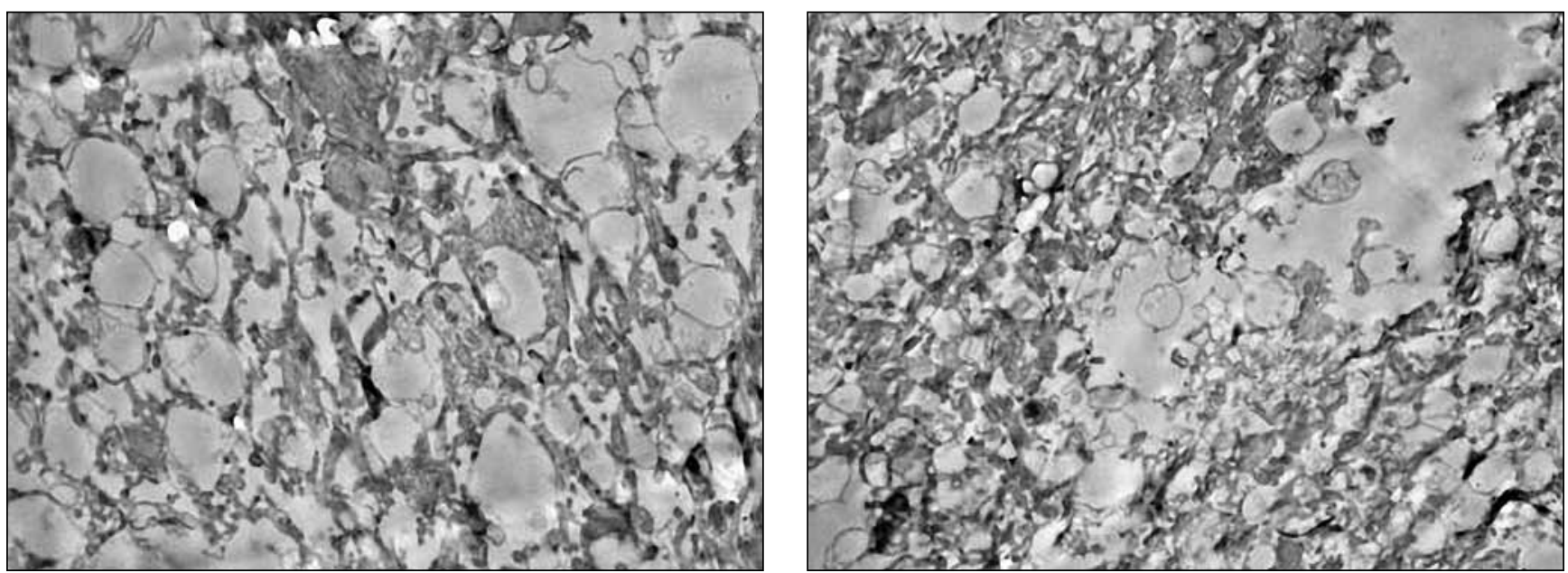

Figure 5: Examples for new onset hydrocephalus cases are viewed under X5000 magnification. Cells are gathered around heaps of amorphic flocculant material. No collagen bundles are observed among the cells. 

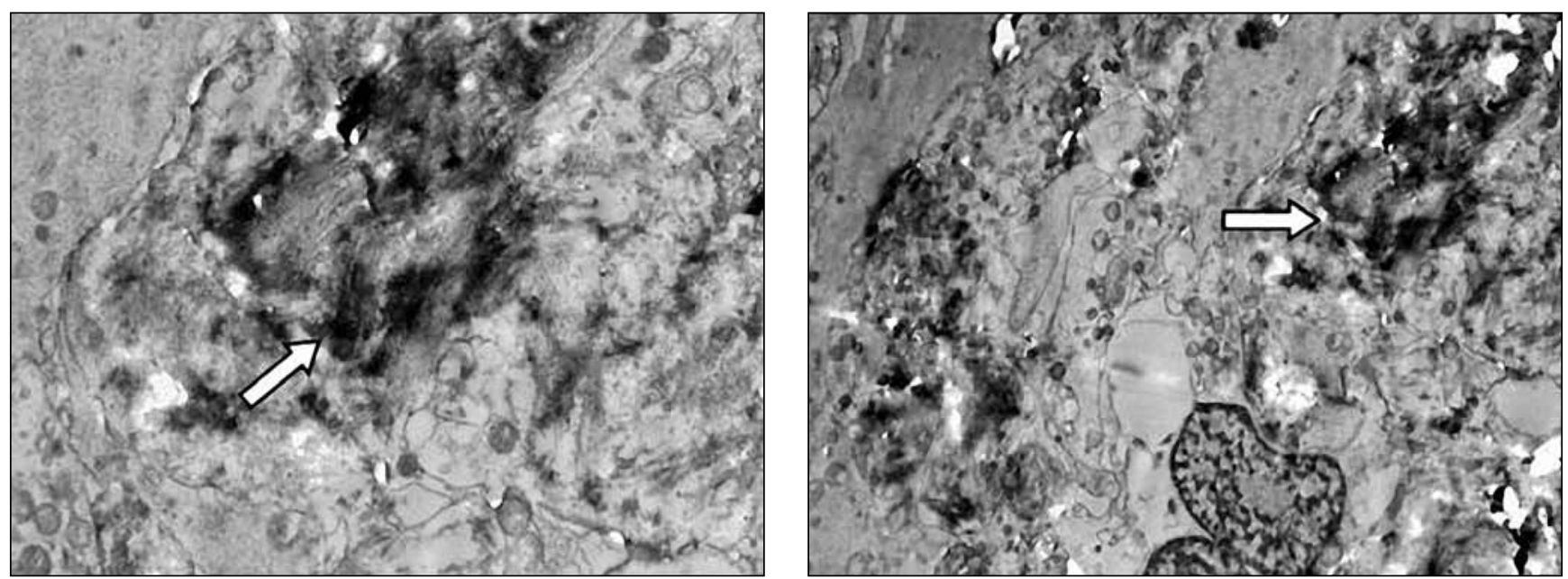

Figure 6: Examples for longstanding hydrocephalus cases. Top is viewed under X7500 magnification and bottom is viewed under X5000 magnification Cells are showing fibroblast morphology (arrows).
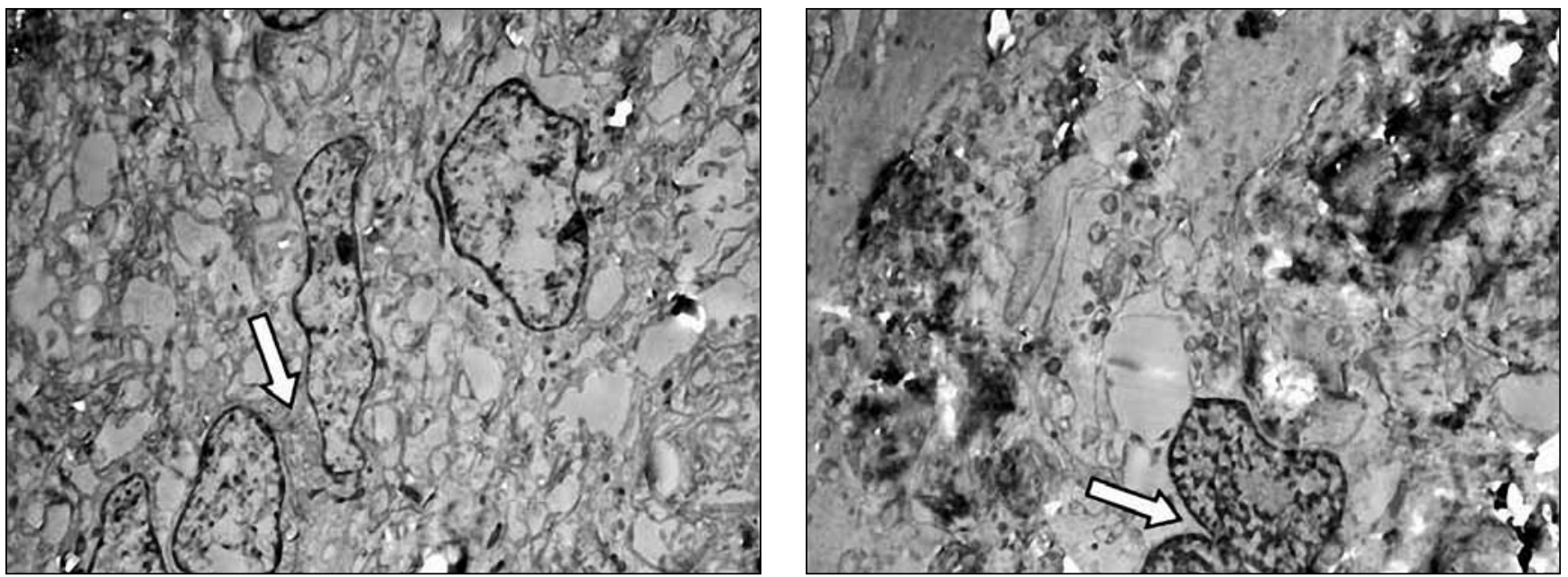

Figure 7: Examples for longstanding hydrocephalus cases are viewed under X5000 magnification. The cells with ovoid shaped nuclei are closely connected by dense desmosomes (arrow top) and gap-junctions (arrow bottom).
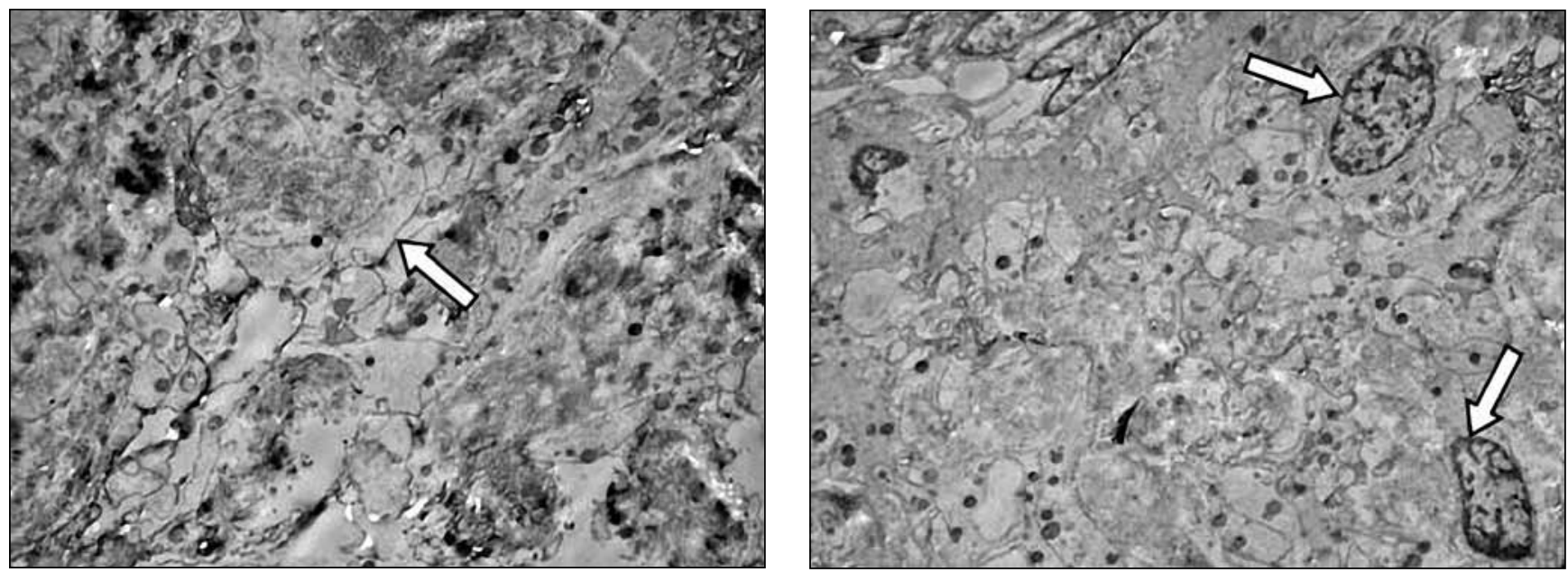

Figure 8: Examples for longstanding hydrocephalus cases are viewed under X5000 magnification. Among collagen bundles, cells (arrows) are observed with their ovoid shaped nuclei and having actin filaments in their dark cytoplasms. 

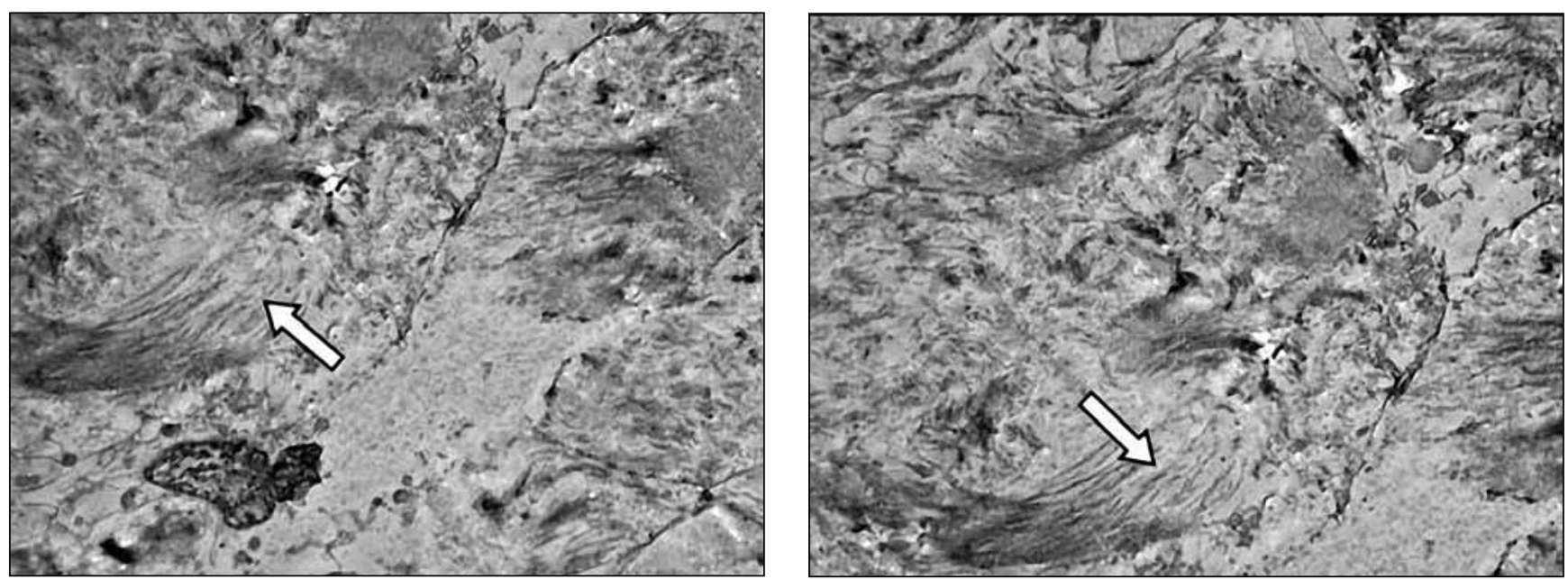

Figure 9: Examples for longstanding hydrocephalus cases are viewed under X5000 magnification. Regular and dense bundles of type-I collagen (arrows) are seen among the fibroblast-like cells.

\section{DISCUSSION}

The Liliequist membrane was described by Key and Retzius in 1875 (7). In 1956, Liliequist rediscovered the structure in his pneumoencephalographic studies of cadavers, which revealed this arachnoid membrane to be arising from the dorsum sellae to the anterior edge of the mammillary body $(8,9)$. In 2000, Zhang and An reported that the Liliequist membrane is a fold of the arachnoid mater and its arachnoid trabecular network has very wide connections with surrounding structures and that the borders of the irregular network may vary widely among individuals (18).

Three segments of the Liliequist membrane have been defined; namely sellar, diencephalic, and mesencephalic (10). Among these, the diencephalic leaf represents special interest for the endoscopic surgeon. The diencephalic leaf of the Liliequist membrane is attached to the infundibulum and pituitary stalk and to the mammillary bodies, is connected by thick arachnoid trabeculas to the bifurcation of the basilar artery, the precommunication part posterior cerebral arteries, with free edge of the diencephalic-mesencephalic leaf of Liliequist membrane which is in turn connected by arachnoid trabeculas to posterior communicating arteries, superior cerebellar arteries, the posterior perforated substance, and forms walls of the oculomotor cistern (14). The region of the subarachnoid space anterior and posterior to the diencephalic leaf can only communicate through the narrow space between the free superior margin of the diencephalic leaf, the optic tract, and the mesial surface of the temporal lobe, and through the gap around the PCoA in cases where it penetrates the diencephalic leaf (10). Thus, fenestrating the diencephalic leaf of the Liliequist membrane to create a total opening in the interpeduncular cistern may greatly increase the flow of CSF into the prepontine cistern, which is extremely important in the ETV procedure.
As the ETV technique has gained popularity in the management of hydrocephalus, the Liliequist membrane has come to be considered an important structure. In recent years, various reports have been published in the literature which focused on the microsurgical anatomy $(10,14,18)$ and the radiological features of the Liliequist membrane (5).

Buxton et al. were the first authors to discuss the role of Liliequist membrane in minimally invasive endoscopic neurosurgery in detail. They proposed that the Liliequist membrane, which is not fenestrated during ETV, may have blocked the flow of CSF from the third ventricle and lead to failure of the procedure (1). In the following years, the importance of Liliequist membrane perforation in the success of the ETV procedure was also noted by various authors ( 6 , $13,14)$.

In recent years, the role of the Liliequist membrane in the failed ETV procedure has been stressed by several reports which emphasized that an unnoticed or intact Liliequist membrane is one of the main causes of ETV failure $(3,4,6,15)$.

In our experience with more than 250 ETV procedures in the last 10 years, we have observed that the Liliequist membrane was usually thick and tough in long-standing hydrocephalus cases, as compared to its usual arachnoidal membrane-like structure observed in new-onset hydrocephalus. Such a tough structure of the Liliequist membrane has frequently led the ETV procedure to become technically much more demanding during its fenestration. This observation made us suggest that the duration of hydrocephalus might have contributed to those changes in the structure of Liliequist membrane.

It is well known that long-standing hydrocephalus and raised intracranial pressure can lead to unusual variations and anatomical changes in the ventricular system. Anatomical distortion of the third ventricular floor has been reported to likely develop with the presence of a long-standing pressure gradient between the third ventricle and the subarachnoid 
space (11). Also Oi et al. have suggested that long-standing noncommunicating hydrocephalus revealed unique pathophysiological and chronological changes in the brain and the duration of hydrocephalus might contribute to the association of various intraventricular anomalies (12).

However, no mention was made of the structural variations of the Liliequist membrane in long-standing hydrocephalus process up to now. In the present study, we intended to confirm and demonstrate the possible changes in the structure of the Liliequist membrane in the long-standing hydrocephalus process. The tissue specimens that have been obtained during the fenestration of Liliequist membrane in ETV procedures of both long-standing and newly-onset hydrocephalus cases were examined under the transmission electron microscope. The main reason for chosing transmission electron microscopic examination was our suggestion that the thickening of the Liliequist membrane might have been the consequence of a fibrosis process in long-standing hydrocephalus. Transmission electron microscopy has emerged as an ideal tool for the study and diagnosis of various disorders that involve structural alterations of collagen fibrils, since the information obtained by this technique is at the ultrastructural level (16).

The results of the ultrastructural evaluation revealed that the Liliequist membrane showed a marked increase in amount and density of type-I collagen bundles in longstanding hydrocephalus cases as compared to newly-onset hydrocephalus cases. Also the cells observed in longstanding hydrocephalus cases mostly displayed active fibroblast morphology with ovoid-shaped nuclei and dark cytoplasms including actin filaments. When compared to the ultrastructural findings of the new-onset hydrocephalus cases, which revealed the existence of cells usually resembling flat fibroblasts and a poor content of sparse collagen bundles, the findings in long-standing hydrocephalus cases suggested a fibrosis process in the Liliequist membrane. Another remarkable difference between the two patient groups was the pattern of the intercellular junctions. In long-standing hydrocephalus cases, the cells were observed to be closely connected by dense desmosomes and gap-junctions, whereas the usual connection type between the cells was loose desmosomes in newly-onset hydrocephalus cases. In the study regarding the ultrastructural analysis of the human meninges, Weller reported that the outer parietal layer of the arachnoid was impermeable to CSF due to tight intercellular junctions; elsewhere leptomeningeal cells were observed to form loose demosomes and gap junctions (17). Considering the relatively closer connection pattern of the cells by dense desmosomes and gap-junctions, we may also suggest that the permeability of the Liliequist membrane to CSF may decrease in long-standing hydrocephalus. This can be the consequence of the fibrosis process, which seems to be provoked by the long duration of the hydrocephalic state.

The above mentioned changes in the structure of the Liliequist membrane in long-standing hydrocephalus cases seem to support our observations in the ETV procedures of those cases, where we frequently encountered thick and tough membranes. Although the number of the cases is small, our results seem to suggest an increase in fibrous construction of the Liliequist membrane in cases with longstanding hydrocephalus.

Regarding the surgical technique, the Liliequist membrane with such a dense and tough structure usually makes the ETV procedure technically demanding. The endoscopic fenestration of the Liliequist membrane may therefore be problematic in long-standing hydrocephalus cases because of its tough structure. Different techniques are used to perforate the Liliequist membrane in the interpedincular cistern. The opening can be carried out in the simplest possible way using conventional instruments for endoscopy (monopolar coagulating probes, balloon catheter) or specific instruments developed for the fenestration of the third ventricle floor. After perforation, a mild balloon dilatation is usually needed to maintain an adequate corridor for the CSF flow. In our technique of performing ETV, we usually use the tip of the monopolar coagulating probe or the balloon catheter for making a blunt perforation in the Liliequist membrane near to its attachment site to the dorsum sella. We strongly advise against using lasers or any type of hot, coagulating energy for the perforation of the Liliequist membrane. The use of these devices may eventually result in an inadvertent injury to the basilar artery and its perforating vessels or to the oculomotor nerve. We usually prefer to cut out or tear off a small piece of membrane gently by using endoscissors or grasping forceps in order to maintain an adequate opening in the Liliequist membrane. We feel that this maneuver is quite helpful in case of dense and thick membranes, since it usually is not possible to perform balloon dilatation because of the tough structure of the Liliequist membrane. In cases where the interpedincular cistern is quite narrow, balloon dilatation of the membrane may carry a risk of direct mechanical pressure to the contents of the interpeduncular cistern. In such cases, the above-stated surgical technique is also helpful to maintain an adequate corridor in the Liliequist membrane. However, this surgical maneuver should be performed by experienced neuroendoscopists since important vascular and neural elements of the interpedincular cistern may easily be injured with inadequate sharp dissection or forceps traction.

The technique of ETV procedure is quite safe in experienced hands, if the intraventricular anatomical landmarks are easily identified and the structure of the surgical targets are normal. However, this procedure may become quite difficult and full of risk in patients with abnormal anatomy or with structurally altered anatomic parts $(2,11)$.

Concerning the results of the current study, one must keep in mind that the structure of the Liliequist membrane may be changed due to the long-standing hydrocephalic process. We believe that the ETV technique may become demanding in long-standing hydrocephalus cases for inexperienced endoscopists because of the thickened and dense structure of the Liliequist membrane. 


\section{REFERENCES}

1. Buxton $\mathrm{N}$, Vloeberghs $\mathrm{M}$, Punt J: Liliequist's membrane in minimally invasive endoscopic neuroendoscopy. Clin Anat 11:187-190, 1998

2. Etus V, Ceylan S: The role of endoscopic third ventriculostomy in the treatment of triventricular hydrocephalus seen in children with achondroplasia. J Neurosurg 103: 260-265, 2005

3. Feng $\mathrm{H}$, Huang $\mathrm{G}$, Liao X, Fu K, Tan $\mathrm{H}, \mathrm{Pu} \mathrm{H}$, Cheng Y, Liu W, Zhao $\mathrm{D}$ : Endoscopic third ventriculostomy in the management of obstructive hydrocephalus: An outcome analysis. J Neurosurg 100:626-633, 2004

4. Fukuhara T, Vorster SJ, Luciano MG: Risk factors for failure of endoscopic third ventriculostomy for obstructive hydrocephalus. Neurosurgery 46:1100-1109, 2000

5. Fushimi Y, Miki Y, Ueba T, Kanagaki M, Takahashi T, Yamamoto A, Haque TL, Konishi J, Takahashi JA, Hashimoto N, Konishi $\mathrm{J}$ : Liliequist Membrane: three-dimensional constructive interference in steady state MR imaging. Radiology 229: 360-365, 2003

6. Hellwig D, Grotenhuis JA, Tirakotai W, Riegel T, Schulte MD, Bauer BL, Bertalanffy $\mathrm{H}$ : Endoscopic third ventriculostomy for obstructive hydrocephalus. Neurosurg Rev 28:1-34, 2005

7. Key A, Retzius G: Studien in der anatomie des nervensystems und des bindegewebs. Stockholm, Norstedt \& Soner, 1875: 111-123

8. Liliequist B: The anatomy of the subarachnoid cisterns. Acta Radiol 46:61-71, 1956
9. Liliequist B: The subarachnoid cisterns: An anatomic and roentgenologic study. Acta Radiol 185:1-108, 1959

10. Lü J, Zhu X: Microsurgical anatomy of the interpeduncular cistern and related arachnoid membranes. J Neurosurg 103: 337-341, 2005

11. Morota N, Watabe $T$, Inukai $T$, Hongo $K$, Nakagawa $H$ : Anatomical variants in the floor of the third ventricle; implications for endoscopic third ventriculostomy. J Neurol Neurosurg Psychiatry 69:531-534, 2000

12. Oi S, Shimoda M, Shibata M, Honda Y, Togo K, Shinoda M, Tsugane R, Sato O: Pathophysiology of long-standing overt ventriculomegaly in adults. J Neurosurg 92:933-940, 2000

13. Schroeder HW, Niendorf WR, Gaab MR: Complications of endoscopic third ventriculostomy. J Neurosurg 96: 1032-1040, 2002

14. Sufianov AA, Sufianova GZ, lakimov IA: Microsurgical study of the interpeduncular cistern and its communication with adjoining cisterns. Childs Nerv Syst 25:301-308, 2009

15. Takehira N, Kang Y, Kanemoto M, Nishikawa, Wage S: Unsuccessful third ventriculostomy. Minim Invasive Neurosurg 46:240-242, 2003

16. Tzaphlidou M: Abnormal collagen fibril structure as studied by electron microscopy. Electron Microsc Rev 5:25-35, 1992

17. Weller RO: Microscopic morphology and histology of the human meninges. Morphologie 89:22-34, 2005

18. Zhang M, An PC: Liliequist's membrane is a fold of the arachnoid mater: Study using sheet plastination and scanning electron microscopy. Neurosurgery 47:902-908, 2000 